\title{
Motion analysis of hoof wall, sole and frog under cyclic load in vitro: Deformation of the equine hoof shod with regular horse shoe, straight bar shoe and bare hoof
}

\author{
Christine Hinterhofer, Norbert Weißbacher, Hans H. F. Buchner, Christian Peham und Christian Stanek \\ Clinic for Orthopaedics in Ungulates, Department V, University of Veterinary Medicine Vienna
}

\begin{abstract}
Summary
In a cadaver limb study 8 right and 8 left equine forelimbs of orthopaedically sound, adult warmblood horses were analysed with a kinematic system. A total of 10 reflective markers were fixed to the dorsal wall, the lateral or medial wall and heel, to the sole and to the frog; limbs were vertically loaded up to $3000 \mathrm{~N}$ with a cycling load imitating the regular walk. Hooves were shod with a straight bar horse shoe, the bar then cut out after the first 10 load cycles, leaving a regular horse shoe, which was finally removed to create the bare hoof situation. 10 kinematic markers were used to register motion via 3 digital cameras in $60 \mathrm{~Hz}$ sample frequency, data then being transformed to a three dimensional motion model. Deformation of the dorsal wall was a dorsopalmar depression. Amount of displacement in the direction of the horn tubules was measured close to $0.5 \mathrm{~mm}$ for all hooves near to the coronary band, displacement in the direction $90^{\circ}$ to the run of the horn tubules at the same location was found $0.8 \mathrm{~mm}$ for bare hooves and $0.5 \mathrm{~mm}$ for shod specimen. Vertical displacements of sole and frog markers reached $1.6 \mathrm{~mm}$ in the bare hooves. The lateral walls displaced mainly inwards and, as the dorsal wall markers, with a higher amount of displacement proximal $(0.5 \mathrm{~mm})$ than distal. Medial markers showed inward or outward displacements with no correlation to shoeing or position. The difference in motion of the hoof capsules comparing the use of the regular horse shoe and the straight bar shoe was found mainly in the sole and frog displacement, namely allowing more depression without the bar. The fixation of horse shoes to the hooves in general resulted in an obvious restriction of the hoof capsules ' deformation.
\end{abstract}

Keywords: horse, hoof mechanics, shoeing, straight bar shoe, motion analysis

Bewegungsanalyse der Hornwand, der Sohle und des Strahls unter zyklischer Belastung in vitro: Verformung des Pferdehufes in Abhängigkeit vom Beschlag und barfuß

In einer Leichenteilstudie wurden 8 linke und 8 rechte Vorderbeine von orthopädisch gesunden Warmblutpferden an einer hydraulischen Belastungsmaschine bezüglich der Bewegungen der jeweiligen Hornkapseln in Abhängigkeit von drei Fußungssituationen kinematisch getestet. Die Hufe waren mit einem geschlossen Hufeisen beschlagen und unter einer Belastung von $3000 \mathrm{~N}$ geprüft. Der Steg des Hufeisens wurde nach den ersten 10 Belastungszyklen entfernt. Der jeweilige Huf wurde dann mit dem nun offenen Hufeisen getestet und letztlich das Hufeisen für die dritte Überprüfung ganz entfernt. Die kinematischen Marker verblieben bei allen Testzyklen an der gleichen Stelle, an den rechten Hufen an der Dorsalwand, der medialen Seitenwand, der medialen Trachtenwand und an Sohle und Strahl, an den linken Hufen entsprechend, aber an der lateralen Seiten- und Trachtenwand. Die Bewegungen unter Belastung wurden mit einer Frequenz von $60 \mathrm{~Hz}$ von drei 2Videokameras erfasst und über das Bewegungsanalyseprogramm 2expert-vision ${ }^{\circledR}$ in ein Bewegungsmodell übergeführt und quantitativ ausgewertet. Die Verformung der Zehenwand erfolgte als palmarodistale Absenkung. Das Ausmaß der Bewegung in Röhrchenrichtung lag zwischen - 0,3 und -0,45 mm in den proximalen Markern. Das Ausmaß der Bewegung der dorsalen Hornwand in der Bewegungsrichtung $90^{\circ}$ zur Röhrchenrichtung in sagittaler Ebene wurde zwischen -0,44 und -0,75 mm gemessen. Die Bewegung aller Dorsalwandmarker war proximal größer als distal, das Bewegungsausmaß generell war geringer bei den beschlagenen Hufen. Die Sohlen- und Strahlmarker zeigten ausschließlich vertikale Bewegungen. Das Ausmaß der Absenkung der Sohle war in beiden Beschlagssituationen ähnlich $(0,73-0,78 \mathrm{~mm})$ und war deutlich größer an den Barhufen (1,12 mm). Die Absenkung des Strahls hingegen war vergleichbar an den Barhufen und den Hufen mit regulärem Beschlag (1,39-1,26 mm) und wurde durch den geraden, die Schenkelenden des Hufeisens verbindenden Steg, auf durchschnittlich $1,11 \mathrm{~mm}$ reduziert. Die vertikalen Bewegungen der Seitenwände waren proximal größer $(-0,33$ bis $-0,72 \mathrm{~mm})$ als distal $(-0,19$ bis $-0,65 \mathrm{~mm})$. Die Seitenwände der Barhufe zeigten größere Verformungen $(0,26-0,72 \mathrm{~mm})$ als die der beschlagenen Hufe (0,12-0,49 mm). Die vertikalen Bewegungen der Trachtenwände waren proximal und distal gleich groß. Beim Vergleich der Beschlagssituationen wurde festgestellt, dass sich die medialen Trachtenwände an den Barhufen (-0,62 bis $-0,64$ mm) deutlich mehr bewegten als an den beschlagenen Hufen $(-0,12$ bis $-0,24 \mathrm{~mm})$. Die vertikalen Verformungen der lateralen Trachtenwände zeigten keine Korrelation zu Markerposition oder Beschlagssituation. Die axiale/abaxiale Verformungen der medialen Seiten- und Trachtenwände wurden sowohl als Einwärts- als auch als Auswärtsbewegung festgestellt. Das Ausmaß der Bewegungen (Seitenwände: -0,71 bis 1,01 mm; Trachtenwände - 1,04 bis 1,23 mm) stand in keiner Abhängigkeit zu Position oder Beschlag, etwa 50 \% der Hufe bewegten sich einwärts, die anderen auswärts. Die axiale/abaxiale Verformungen der lateralen Seitenwand waren fast ausschließlich nach innen gerichtet, proximal deutlicher (-0,1 bis - 1,58 mm) als distal (-0,01 bis -1,34 mm). Die Beschlagssituation hatte keinen Einfluss auf das Ausmaß der Bewegung. Die axiale/abaxiale Bewegung der lateralen Trachtenwand war mehrheitlich einwärts gerichtet an den proximalen Markern (-0,62 bis 0,31 mm) und zeigte Einwärts- und Auswärtsbewegungen an den distalen Markern (-0,62 bis 0,33 mm), mit nur geringer Korrelation zu den Beschlagssituationen. Die Bewegungen der Seiten- und Trachtenwände des Pferdes kann nun nicht mehr ausschließlich als Erweiterung angesprochen werden. Von klinischer Relevanz ist, dass der Hufbeschlag im Bereich der gemessenen Hornkapselteile eine deutliche Bewegungsrestriktion zur Folge hat. Diese Einschränkung wirkt sich an der Zehenwand, der Seitenwand und der Sohlenfläche stärker aus als an den Trachten und der medialen Wand.

Schlüsselwörter: Pferd, Hufmechanismus, Hufbeschlag, geschlossene Hufeisen, Bewegungsanalyse 


\section{Introduction}

The equine hoof represents a very strong and resistant part of the horses ' limb. Interaction with the ground in the sense of weight bearing, shock absorption and corrective balance is ideally possible in the bare hoof, but the use of horses in sport, work and pleasure riding and driving often makes the horses' health dependent on a protective and supportive horse shoe (Habacher 1923, Butler 1993). Thorough research had been performed with regard to the influence of shoeing on the equine hoof capsule (Colles 1998, Hinterhofer et al. 2002, Jordan et al. 2001, Roepstorff et al. 1999, Thomason 1998, Weißbacher 2001) and the distal limb (Willemen et al.1997, Wilson et al., 2001). The connection of the hard and rigid rim to the hoof wall though has to a degree still unknown consequences for the hoof wall, the force transmission, the hoof deformations and subsequently the backflow of the blood (Lechner 1904, Koenig et al. 2003b).

The strong hoof capsule consists of the hoof wall, bars, sole and frog (Bolliger and Geyer 1992, Kainer 1989) and protects the coffin joint, the soft digital cushion (Koenig et al. 2003a), tendons and ligaments and the horn producing lamina. Load transmission proceeds mainly via the suspensory apparatus (Budras et al. 1996) and is highly responsible of the hoof capsules deformation (Fischerleitner 1974). These movements are rather uniformly described in farriers ' and veterinarians ' literature as the spreading of the heels, the lowering of the sole, the downward and backward movement of the dorsal wall and the outward movement of the lateral and medial wall (Habacher 1923, Butler 1993, Parks 2003) and material research also concluded comparable deformations (Douglas et al. 1996, Hinterhofer et al. 2001). In contrast, literature from the beginning of last century (Lechner 1904) addressed sidewall displacement as inward or rotational movement and some recent investigations (Burn and Brockington 2001, Woergetter et al. 2006) found similar results. For this study dissected cadaver limbs were used to measure deformation of the hoof capsule. Main interest was focussed on the influence of different horse shoes compared to the bare loaded hoof and the amount and direction of sidewalls' movement.

\section{Material and Methods}

16 front limbs of 8 adult warm blood horses, euthanised for reasons other than this study, were tested. Digits were selected with respect to orthopaedic soundness, straight toe axis in anterior-posterior view and from the side, with hooves of regular shape and good horn quality. The toes were disarticulated in the radio carpal joints to preserve the intact connection of the distal check ligament of the DDFT. Hooves were cleaned and trimmed to present a flat and even solar surface. Specimens were wrapped in plastic and deep frozen at $-18^{\circ} \mathrm{C}$. Preceding the testing the limbs were slowly warmed to room temperature over a period of 12 hours. Measures were taken of the dorsal and lateral hoof angle, circumflexion of the coronet and the weight bearing rim, length of the dorsal wall, of the lateral and medial wall at the quarters, maximum width of the hooves at the solar surface and the length of the frog and of the solar part between the apex of the frog and the dorsal point of the weight bearing rim (Tab. 1) to be put in correlation with the deformations.
A closed horse shoe, $8 \mathrm{~mm}$ thick, with a straight bar was fixed to the hoof with 2 hoof nails on each side. In none of the hooves the frog had contact to the straight bar when loaded. In the course of testing the straight bar was cut out to leave a regular horse shoe and finally the shoe was taken off. These procedures were done with thorough care to preserve the markers' positions (see below).

\section{Markers and recording procedure}

Round reflective markers with a diameter of $10 \mathrm{~mm}$ were used, three glued to the dorsal wall, three to the lateral or medial wall and two markers were glued to the heels in positions, which were proportional to the segments length (Fig. 1). The right hooves were tested for medial wall deformation, the left hooves were tested for lateral wall deformation, because the loading device of the machine did not allow positioning of the cameras all around. In addition, one marker was used for the sole and one for the frog. Strain gauges were pasted to the dorsal wall and the lateral or medial wall; these results are not presented here.

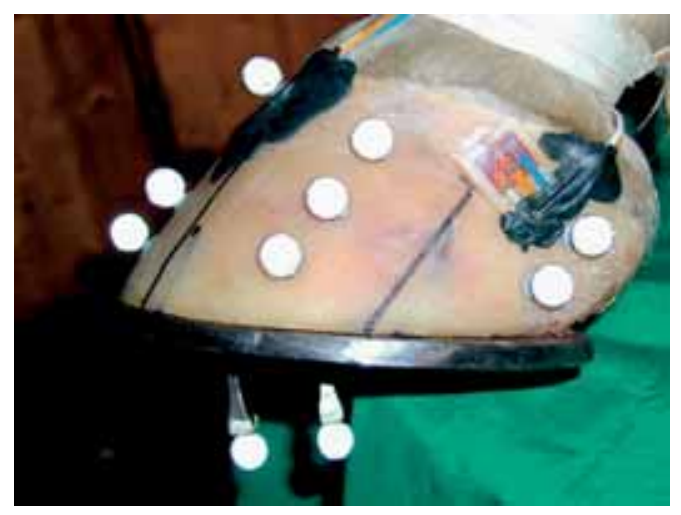

Fig 1 Hoof specimen prepared with kinematic markers for motion capture of the dorsal wall, the lateral wall, the heel, the sole and the frog. Strain gauges were also attached, but results are not shown in this paper.

Limb specimens were fixed to the testing device of the 1 machine via a metal pin of $10 \mathrm{~mm}$ diameter running horizontally through the proximal cannon bone, perpendicular to the direction of movement. Limbs were vertically loaded with a $1 \mathrm{~Hz}$ sinusoidally cycling force with amplitudes to $3000 \mathrm{~N}$, comparable to forces acting at some stage in regular walk (Thomason, 1998). Hooves were positioned on a steel plate with polished surface with a central opening to allow the sole and frog markers to move freely. Three high-speed video 2 cameras with a resolution of $833 \times 240$, and equipped with red light flashing working at $60 \mathrm{~Hz}$ were positioned to optimally capture the markers reflections. Calibration was performed by cube calibration, using 8 kinematic markers in defined distances, and by wall calibration, where a $15 \mathrm{~cm}$ stick with three markers was moved in the system to calculate the positions of the markers in the coordinate system. For each hoof 900 measures of the first ten load cycles were included in the calculations of the three dimensional displacement model via 2 expert-vision. Hoof 1 had to be excluded after the testing because of technical difficulties with the testing machine.

Deformations were expressed in $\mathrm{mm}$, listed according to marker and position and examined in relation to the three footing 
situations. Displacement was evaluated in the direction of the horn tubules (DT) and $90^{\circ}$ to the horn tubules in the sagittal plane for the dorsal wall, in vertical displacements (VD) for all tested segments but the dorsal wall and in axial /abaxial displacement (AD) for the lateral and medial wall and heel segments. Deformation results of right and left hooves of the dorsal wall (DT and $90^{\circ}$ ), of sole and frog markers (VD) and of sidewall and heel markers in VD were compared using a test showing no significant difference between mean values. Subsequently, data of right and left hooves 'results were averaged (Tab. 2). Axial/abaxial displacements of lateral and medial wall sections were dealt with separately (Tab.3). Data did not prove to be in normal distribution with regard to the

Table 1: Single measures and mean values of 16 front hooves in $\mathrm{cm}$, angles in degrees ${ }^{\circ}$. Lateral wall angles were measured of left hooves, medial wall angles were measured of right hooves. Abbreviations: DWA = dorsal wall angle, LWA = lateral wall angle, $M W A=$ medial wall angle, $\mathrm{DL}=$ length of dorsal wall, $\mathrm{QL}=$ length of the hoof wall at the quarters, CC = circumflexion length at the coronet, $\mathrm{CW}=$ circumflexion length at the weight bearing rim, $\mathrm{MW}=$ maximum width of the solar surface, $\mathrm{FL}=$ length of the frog, $\mathrm{SL}=$ distance between the apex of the frog and the dorsal point of the weight bearing rim.

\begin{tabular}{|c|c|c|c|c|c|c|c|c|c|c|c|}
\hline hoof $\mathrm{nr}$ & right/left & DWA & LWA & MWA & DL & QL & CC & CW & MW & FL & SL \\
\hline & & ${ }^{\circ}$ & ${ }^{\circ}$ & ${ }^{\circ}$ & $\mathrm{cm}$ & $\mathrm{cm}$ & $\mathrm{cm}$ & $\mathrm{cm}$ & $\mathrm{cm}$ & $\mathrm{cm}$ & $\mathrm{cm}$ \\
\hline 1 & left & 55 & 88 & - & 10.4 & 7.2 & 35.2 & 38.5 & 12.1 & 9.1 & 4.2 \\
\hline 2 & right & 53 & - & 82 & 10.4 & 7.4 & 35.6 & 39.0 & 12.2 & 9.2 & 4.0 \\
\hline 3 & right & 55 & - & 87 & 8.2 & 6.6 & 32.0 & 34.0 & 11.6 & 9.2 & 4.0 \\
\hline 4 & left & 56 & 79 & - & 7.9 & 6.6 & 31.5 & 33.5 & 11.3 & 9.0 & 4.6 \\
\hline 5 & left & 55 & 82 & - & 8.6 & 7.1 & 31.0 & 32.5 & 11.1 & 9.0 & 4.2 \\
\hline 6 & right & 57 & - & 80 & 8.3 & 6.5 & 32.5 & 34.0 & 10.7 & 9.0 & 4.2 \\
\hline 7 & left & 51 & 83 & - & 9.7 & 7.8 & 33.0 & 37.5 & 12.2 & 9.3 & 6.0 \\
\hline 8 & right & 50 & - & 83 & 9.5 & 7.2 & 33.0 & 39.0 & 13.0 & 9.4 & 5.9 \\
\hline 9 & right & 59 & - & 88 & 10.8 & 10.1 & 40.0 & 42.5 & 14.4 & 11.0 & 5.2 \\
\hline 10 & left & 56 & 87 & - & 11.2 & 8.8 & 40.0 & 44.3 & 14.6 & 11.2 & 5.4 \\
\hline 11 & left & 53 & 90 & - & 9.0 & 8.0 & 35.0 & 37.3 & 13.9 & 10.0 & 4.5 \\
\hline 12 & right & 54 & - & 81 & 9.4 & 7.7 & 35.0 & 39.0 & 14.1 & 10.4 & 4.8 \\
\hline 13 & right & 56 & - & 83 & 8.5 & 7.2 & 35.0 & 38.0 & 12.2 & 10.4 & 4.4 \\
\hline 14 & left & 53 & 83 & - & 9.3 & 7.6 & 33.5 & 37.2 & 12.3 & 10.2 & 4.6 \\
\hline 15 & left & 55 & 79 & - & 9.0 & 7.6 & 34.5 & 38.2 & 12.4 & 10.4 & 4.4 \\
\hline 16 & right & 56 & - & 85 & 8.5 & 6.5 & 34.5 & 37.5 & 11.7 & 9.7 & 4.1 \\
\hline mean & & 55 & 82.8 & 83.6 & 9.3 & 7.5 & 34.5 & 37.6 & 12.5 & 9.8 & 4.7 \\
\hline sd & & 2.2 & 3.6 & 3.8 & 1.0 & 0.9 & 2.6 & 3.1 & 1.2 & 0.7 & 0.6 \\
\hline
\end{tabular}

direction (inward/outward). Correlations of $A D$ of the single wall sections to the footing situations were calculated using the absolute displacement values, which were then normally distributed.

\section{Statistics}

Data acquired were analysed using SPSS 9.0 based on the general linear model. The Kolmogorov-Smirnov test was applied and proved the normal distribution. Differences between groups were tested using the multiple comparison analysis of Scheffé and covariance analysis. Data of right and left hooves were compared using the unpaired heteroeskadic T-test. Correlation between motion capture and hoof measures was defined using the Pearson's correlation test. Significance level was set at $\mathrm{P}<0.05$.

\section{Results}

Hoof measures are to be seen in table 1. No correlation was found between motion analysis results and the obtained hoof angles or dimensions.

Right and left hooves, dorsal wall (M1-M3) - Deformation in the direction of the horn tubules (DT) was found highest for M1 showing values between -0.31 and $-0.45 \mathrm{~mm}$. M2 and M3 showed lesser displacements (-0.01 to $-0.21 \mathrm{~mm})$, but no difference was found between the three footing situations or within the three markers of the dorsal wall (Tab.2)

Displacement in the direction $90^{\circ}$ to the run of the horn tubules was clearly higher in M1 (-0.51 to $-0.75 \mathrm{~mm})$ than more distally. Statistical difference was found between values of M1-3 in all situations. Comparing the footing situations, hooves with regular horse shoes and those with straight bar shoes showed the same range of deformation $(-0.19$ to -0.51 $\mathrm{mm})$. The bare hooves had largest $90^{\circ}$ displacements $(-0.37$ to $-0.75 \mathrm{~mm}$ ) in all dorsal wall markers compared to the shod hooves (Tab.2).

Right and left hooves, sole and frog (M9-M10) - Displacement of sole and frog markers uniformly showed vertical displacement (VD), sole markers dropped to a lesser extent than frog markers. The sole markers showed no differences between the shoeing situations $(0.73-0.78 \mathrm{~mm})$, but the bare hoof allowed clearly larger deformation up to 1.12 $\mathrm{mm}$. For frog makers the hooves with the straight bar shoe had lesser displacement $(1.11 \mathrm{~mm})$ than the hooves with the regular horse shoe and the bare hooves (1.26-1.39 $\mathrm{mm}$ ).

Right and left hooves, VD of sidewalls (M4-M6) - Vertical displacements of the proximal markers (M4) were found larger $(-0.33$ to $-0.72 \mathrm{~mm})$ than of the distal markers $(-0.19$ to $-0.65 \mathrm{~mm})$. The bare hooves showed higher displacements $(0.26-0.72 \mathrm{~mm})$ compared to the shod hooves $(0.12-0.49$ $\mathrm{mm})$.

Right and left hooves, VD of heels $(M 7,8)$ - Vertical displacements of the heels were in the same range for proximal and

Table 2 Mean values in mm and standard deviation of displacements of dorsal wall markers (M1-M3) and sole (M9) and frog (M10) markers of 15 right and left hooves shod with a straight bar shoe (sbs), a regular horse shoe (rhs) and bare (bh); DT: direction of the horn tubules; $90^{\circ}$ : displacement perpendicular to the run of the horn tubules in the sagittal plane; VD: vertical displacement. Letters a - i indicate one situation of one marker within one segment. The according superscripts denote significant differences between the selected position and the superscripted positions ( $p \leq 0.05)$.

\begin{tabular}{|c|c|c|c|c|c|c|c|c|c|c|c|c|c|c|c|c|c|}
\hline & & \multicolumn{3}{|c|}{$\mathrm{M}_{1}$} & \multicolumn{3}{|c|}{$\mathrm{M}_{2}$} & \multicolumn{3}{|c|}{$M_{3}$} & & \multicolumn{3}{|c|}{$M_{9}$} & \multicolumn{3}{|c|}{$M_{10}$} \\
\hline & & sbs & rits & bh & sbs & riss & bh & sbs & rhs & bh & & sbs & rhs & bh & sbs & rins & bh \\
\hline & & a & $b$ & c & d & $\mathrm{e}$ & $f$ & $\mathrm{~g}$ & $\mathrm{~h}$ & i & & & & & & & \\
\hline DT & mean & $-0.4^{d g}$ & $-0.3^{\text {eh }}$ & $-0.45^{f i}$ & $-0.2^{\mathrm{ag}}$ & $-0.07^{\text {bh }}$ & $0.01^{c^{\mathrm{i}}}$ & $-0.17^{\text {od }}$ & $-0.14^{\text {be }}$ & $-0.11^{f f}$ & & & & & & & \\
\hline & sd & 0.23 & 0.31 & 0.41 & 0.30 & 0.29 & 0.16 & 0.26 & 0.21 & 0.13 & & & & & & & \\
\hline & & & & & & & & & & & & $a$ & $b$ & c & d & $\mathrm{e}$ & $f$ \\
\hline $90^{\circ}$ & mean & $-0.51^{\mathrm{dgc}}$ & $-0.44^{\text {ehc }}$ & $-0.75^{\text {fiab }}$ & $-0.25^{\text {agf }}$ & $-0.26^{\text {bhf }}$ & $-0.4^{\text {cide }}$ & $-0.19^{\text {adi }}$ & $-0.19^{\text {bei }}$ & $-0.37^{\text {clgh }}$ & VD & $0.78^{\mathrm{dc}}$ & $0.73^{\mathrm{ec}}$ & $1.12^{\text {fab }}$ & $1.11^{\text {oef }}$ & $1.26^{\text {bd }}$ & $1.39^{\text {cd }}$ \\
\hline & sd & 0.41 & 0.35 & 0.46 & 0.28 & 0.31 & 0.36 & 0.16 & 0.24 & 0.36 & & 0.51 & 0.40 & 0.58 & 0.55 & 0.54 & 0.46 \\
\hline
\end{tabular}


distal markers (-0.12 to $-0.64 \mathrm{~mm})$. The right hooves (medial heels) showed larger deformation when bare, compared to the shod hooves. Vertical displacements of the left hooves' heels showed no correlation with marker position and footing situation. with only no correlation of the absolute displacement with the footing situations. The proximal markers M7 showed displacement values between -0.62 and $0.31 \mathrm{~mm}$; they mainly displaced inwards. The distal lateral walls (M8) displaced between -0.62 and $0.33 \mathrm{~mm}$, deformation of the shod hooves

Table 3 Mean values in $\mathrm{mm}$ and standard deviation of displacements of kinematic markers of the medial sidewall and heel of 8 right hooves (hoof numbers 2,3,6,8,9,12,13,16) and the lateral sidewall and heel of 7 left hooves (hoof numbers 4,5,7,10,1 1, 14,15); shod with a straight bar shoe (sbs), a regular horse shoe (rhs) and bare (bh); VD: vertical displacements; AD: horizontal axial/abaxial direction. Negative values indicate displacements towards the centre of the hoof. Letters a - i indicate one situation of one marker within one segment. The according superscripts denote significant differences between the selected position and the superscript.

\begin{tabular}{|c|c|c|c|c|c|c|c|c|c|c|c|c|c|c|c|c|}
\hline & & \multicolumn{3}{|c|}{$M_{4}$} & \multicolumn{3}{|c|}{$M_{5}$} & \multicolumn{3}{|c|}{$M_{6}$} & \multicolumn{3}{|c|}{$M_{7}$} & \multicolumn{3}{|c|}{$M_{8}$} \\
\hline & & sbs & rhs & bh & sbs & rhs & bh & sbs & rhs & bh & sbs & rhs & bh & sbs & rhs & $b h$ \\
\hline Medial/ & right & $a$ & $b$ & c & $\mathrm{d}$ & $\mathrm{e}$ & $f$ & g & $\mathrm{h}$ & $i$ & $a$ & $b$ & c & $\mathrm{d}$ & $\mathrm{e}$ & $f$ \\
\hline \multirow[t]{3}{*}{ VD } & mean & $-0.39^{\mathrm{dgc}}$ & $-0.46^{\text {ehc }}$ & $-0.72^{\text {fiab }}$ & $-0.32^{\text {agf }}$ & $-0.3^{b f}$ & $-0.65^{\text {cide }}$ & $-0.27^{\text {adi }}$ & $-0.3^{\mathrm{bi}}$ & $-0.58^{\text {ctgh }}$ & $-0.16^{c}$ & $-0.2^{c}$ & $-0.64^{\mathrm{ab}}$ & $-0.24^{f}$ & $-0.12^{f}$ & $-0.62^{\text {de }}$ \\
\hline & sd & 0.26 & 0.26 & 0.27 & 0.21 & 0.16 & 0.27 & 0.21 & 0.16 & 0.23 & 0.57 & 0.48 & 0.61 & 0.35 & 0.34 & 0.61 \\
\hline & hooves & & & & & & & & & & & & & & & \\
\hline \multirow[t]{7}{*}{$A D$} & 2 & 0.21 & 0.51 & 0 & 0.34 & 0.57 & 0.45 & 0.37 & 0.40 & 0.61 & 0.08 & 0.60 & 0.26 & 0.10 & 0.60 & 0.28 \\
\hline & 3 & 0.83 & 0.67 & 0.31 & 0.85 & 0.49 & 0.26 & 1.01 & 0.55 & 0.04 & -0.36 & -0.09 & -0.05 & -0.14 & 0.04 & -0.12 \\
\hline & 6 & -0.68 & -0.71 & -0.10 & -0.50 & -0.56 & -0.07 & -0.36 & -0.34 & 0.13 & 0.49 & -0.6 & -0.12 & -0.20 & -0.35 & 0.01 \\
\hline & 9 & 0.04 & 0.07 & 0.02 & 0.19 & -0.11 & 0.09 & -0.24 & -0.45 & -0.35 & -0.04 & -0.15 & -0.15 & -0.16 & -0.44 & -0.05 \\
\hline & 12 & 0.83 & -0.10 & -0.21 & 0.79 & 0.06 & -0.10 & 0.86 & 0 & 0.01 & 0.8 & -1.04 & -0.21 & 1.23 & -0.28 & -0.48 \\
\hline & 13 & 0.19 & 0.59 & 0.19 & 0.49 & 0.71 & 0.45 & 0.36 & 0.51 & 0.38 & 0.08 & 0.51 & -0.07 & 0.17 & 0.61 & 0.84 \\
\hline & 16 & -0.04 & -0.08 & -0.21 & 0.03 & 0.10 & -0.06 & 0.29 & 0.12 & 0.07 & 0.28 & 0.40 & 0.10 & 0.15 & 0.40 & -0.13 \\
\hline Lateral/ & left & $a$ & $b$ & c & $d$ & $\mathrm{e}$ & $f$ & $g$ & $\mathrm{~h}$ & $\mathrm{i}$ & $a$ & $b$ & c & $\mathrm{d}$ & $\mathrm{e}$ & $f$ \\
\hline \multirow[t]{3}{*}{ VD } & mean & $-0.33^{\mathrm{dgc}}$ & $-0.35^{\text {ehc }}$ & $-0.54^{\text {fiab }}$ & $-0.26^{\text {agf }}$ & $-0.26^{b f}$ & $-0.37^{\text {cide }}$ & $-0.19^{\text {adhi }}$ & $-0.27^{\mathrm{bg}}$ & $-0.26^{\text {ctgh }}$ & -0.37 & -0.49 & -0.60 & -0.38 & -0.40 & -0.40 \\
\hline & $\mathrm{sd}$ & 0.08 & 0.09 & 0.16 & 0.16 & 0.25 & 0.24 & 0.16 & 0.17 & 0.18 & 0.35 & 0.48 & 0.62 & 0.22 & 0.44 & 0.50 \\
\hline & hoove & & & & & & & & & & & & & & & \\
\hline \multirow{6}{*}{$A D$} & 5 & -0.31 & -0.22 & -0.72 & -0.20 & -0.11 & -0.44 & -0.16 & -0.08 & -0.20 & -0.13 & 0.31 & -0.53 & 0.22 & 0.08 & -0.25 \\
\hline & 7 & -0.10 & -0.36 & -0.19 & -0.12 & -0.20 & -0.20 & 0.15 & -0.15 & -0.06 & -0.30 & -0.15 & -0.26 & -0.27 & -0.26 & -0.33 \\
\hline & 10 & -0.66 & -0.55 & -0.26 & -0.55 & -0.47 & -0.34 & -0.34 & -0.25 & -0.23 & -0.60 & 0.05 & -0.14 & -0.49 & 0.20 & -0.37 \\
\hline & 11 & -0.80 & -0.67 & -0.70 & -0.61 & -0.45 & -0.46 & -0.41 & -0.28 & -0.22 & -0.23 & -0.18 & 0.08 & -0.24 & -0.14 & -0.27 \\
\hline & 14 & -1.58 & -1.35 & -0.95 & -1.08 & -0.91 & -1.34 & -0.74 & -0.79 & -0.05 & -0.17 & -0.58 & -0.62 & 0.09 & -0.27 & -0.17 \\
\hline & 15 & -0.20 & -0.34 & -0.45 & -0.09 & -0.11 & -0.02 & 0.11 & 0.08 & 0.28 & -0.11 & -0.03 & 0.13 & 0.02 & 0.13 & 0.07 \\
\hline Absolute & displ. & $a$ & $\mathrm{~b}$ & c & $d$ & $\mathrm{e}$ & $f$ & $g$ & $\mathrm{~h}$ & $\mathrm{i}$ & $a$ & $\mathrm{~b}$ & c & $\mathrm{d}$ & $\mathrm{e}$ & $f$ \\
\hline \multirow[t]{3}{*}{ medial } & $A D$ & & & & & & & & & & & & & & & \\
\hline & mean & 0.36 & 0.35 & 0.18 & 0.42 & 0.34 & 0.21 & 0.47 & 0.31 & 0.22 & 0.35 & 0.52 & 0.15 & 0.31 & 0.42 & 0.24 \\
\hline & sd & 0.35 & 0.29 & 0.15 & 0.29 & 0.26 & 0.16 & 0.29 & 0.20 & 0.21 & 0.29 & 0.31 & 0.09 & 0.37 & 0.21 & 0.28 \\
\hline \multirow[t]{3}{*}{ lateral } & $A D$ & & & & & & & & & & & & & & & \\
\hline & mean & $0.57^{d}$ & 0.47 & $0.47^{i}$ & $0.42^{a}$ & 0.34 & 0.41 & 0.37 & 0.35 & $0.15^{c}$ & 0.25 & 0.21 & 0.29 & 0.24 & 0.22 & 0.21 \\
\hline & sd & 0.52 & 0.39 & 0.32 & 0.36 & 0.28 & 0.44 & 0.23 & 0.40 & 0.10 & 0.17 & 0.20 & 0.21 & 0.15 & 0.18 & 0.12 \\
\hline
\end{tabular}

Right hooves, $A D$ of medial walls (M4-M6) - Single mean values (-0.71-1.01 $\mathrm{mm})$ and mean values of absolute displacements are expressed in Tab. 2. About $50 \%$ of the medial walls deformed to the centre of the hoof, and the others displaced outwards. Absolute displacements of medial wall markers in AD did not differ between markers or between the shoeing situations.

Right hooves, $A D$ of medial heels $(M 7,8)$ - Displacement values ranged between -1.04 and $1.23 \mathrm{~mm}$; deformation of the medial heels was to a percentage of $57 \%$ an inward movement, the rest was moving outwards. For absolute displacements no correlation to positions or footing situations was found.

Left hooves, AD of lateral walls (M4 - M6) - The lateral walls in AD deformed predominantly towards the centre of the hoof. The proximal markers showed inward movements between - 0.1 and $-1.58 \mathrm{~mm}$. The M5 markers showed inward movement between -0.02 and $-1.34 \mathrm{~mm}$ and M6 displaced between 0.01 and $-1.13 \mathrm{~mm}$. Shoeing did not influence the amount of the absolute displacement, but there was a tendency of higher displacements in proximal markers than more distally.

Left hooves, $A D$ of lateral heels $(M 7,8)$ - The lateral heels in $A D$ offered both, inward and outward displacement (Tab. 3) was inward or outward, the distal lateral heel of the bare hooves showed mainly a contractive (inward) movement.

Absolute displacements were different between medial and lateral sidewalls in the markers M4 and M5 whereas absolute displacements of medial and lateral heels showed no differences.

\section{Discussion}

Motion capture of equine hooves ' deformation is technically challenging, but achievable using kinematic systems (Burn and Brockington 2001, Jordan et al. 2001, Weißbacher 2001 ), strain gauges (Hansen et al. 2005, Thomason 1998) or digital cameras (Woergetter et al. 2006). Interpretation of motion analysis results of the equine hoof is tricky though with different problems in living horses (Burn and Brockington 2001, Jordan et al. 2001) than in in vitro studies (Hansen et al. 2005, Woergetter et al. 2006). The moving horses hoof does not land in precise distance to the cameras and may include a slipping component and uneven footing. As a result repeated measures at the exact same conditions are difficult to perform. For motion analysis of the hoof in vitro, loading of the limb will be restricted to the situation during midstance, missing the kinematic component of the landing extremity. 
Although motion analysis of the hoof capsule and influences of horse shoes on the equine hoof were investigated on several times (Colles 1989, Hinterhofer et al. 2002, Roepstorff et al. 1999 and 2001), the difficulties of loading the limb in a testing machine and the relation of the obtained data to the according movement phase is still discussed. For this study, the fixation of the limb specimen to the testing machine was performed by using a strong metal pin with smooth and even surface, placed perpendicular through the proximal cannon bone. This allowed a minor palmar rotation of the cannon bone at maximum load with the consecutive and necessary dislocation of the fetlock joint. The hooves did not dislocate under load, the stable footing was verified by the purely vertical displacement of sole and frog markers. The resulting position of the cannon bone in a slight angle to the test platform may be interpreted as the situation shortly after midstance.

Deformation of the equine hoof capsule in the living horse (Butler 1993, Habacher 1923) happens when the hoof interacts with the ground surface. The described deformation pattern (Douglas et al. 1996, Dyhre-Poulsen et al. 1994, Jordan et al. 2001) includes the backward and downward movement of the dorsal wall, the spreading of the heels and the displacement of side walls and heels predominantly described as widening. So far, modelling of hoof deformation based on material research (Douglas et al. 1996, Hinterhofer et al. 2001) also concluded the same movement pattern, which again agreed with strain gauge measurements (Thomason 1998) and other deformation therories (Colles 1989, DyhrePoulson et al. 1994). In contrast, Woergetter et al. (2006) found like Lechner (1904) inconsistencies between the described spreading of the sidewalls and heels and their own results, namely the fact, that some sidewalls and heels did not deform outwards, also cautiously addressed by Burn and Brockington (2001). The aim of this study was to register sidewalls and heels displacements with respect to amount and direction of movement and also in correlation with three different footing situations in order to support the former described spreading of the heels or to add information to the variable sidewalls movement pattern.

In the presented investigation medial and lateral sidewalls and heels did not show a uniform deformation according to the formerly described kind of movement of farriers ' and veterinarians' literature. The lateral wall deformed predominantly inwards, whereas the medial wall showed inward or outward displacements. The lateral sidewall had, as it is known and described for the dorsal wall, a comparable decrease in motion from the coronary band to distal wall parts. The medial sidewall showed similar deformation values in its proximal and distal markers and displaced inwards or outwards. As a conclusion, displacement of the sidewalls and the heels in general is larger in the sections closer to the coronary band, but movement of the sidewalls and heels of the equine hoof can no longer be addressed as uniform widenening. As the geometrical form of the tested hooves does not offer a solution for these varying deformations, the reasons have to be looked for in the internal structures of the hoof, their resistancy against deformation and their geometry.

The influences of horseshoes on the deformation of the equine hoof turned out to be a clear restriction of movement. Hooves segments in the measured directions DT, $90^{\circ}$ and VD generally showed larger displacements when loaded bare foot than when loaded on a horseshoe, even fixed by only 4 hoof nails. This outcome can expected to be even more severe with the use of quarter clips and thoroughly tightened hoof nails in a higher number. The reduction of deformation was predominantly in the same direction, only the lateral heels deformed inward when bare, and outward when shod. The two tested horsehoes, the regular horse shoe and the straight bar shoe, had similar effects, though the closed shoe seemed to reduce the capsules movements even more than the regular horse shoe. Refering to the frog markers and their vertical displacement, there was significant reduction established by the use of the straight bar. It is still unclear and leads to further clinical investigations, to what level this restiriction of movement involve the underlying soft and hard tissue structures and even more of interest is the clinical relevance for the concussion, the blood supply and the subsequent horn production.

\section{Abbreviations}

DDFT deep digital flexor tendon

FE finite elements

FEA finite element analysis

DT deformation in the direction of the horn tubules

VD defomation in vertical direction

AD displacement in axial / abaxial direction

\section{Acknowledgments}

Many thanks go to Kurt Buchmayer for his skillful support in hoof preparation and shoeing.

\section{Manufacturers`addresses}

1 Digital material testing system PCS 200-T1-HS,S/Nr.97; test stand LFV 50/250, S/Nr. 405; pressure oil device Zyp PA 1050R, S/Nr. 195, Walter \& Bay, Schweiz.

2 Expert vision software and digital cameras, Motion Analysis Corporation, California, USA.

\section{Literature}

Bolliger C. and Geyer H. (1992): The equine hoof - morphological and histological findings. Pferdeheilkunde 8, 269-286

Budras K. D., Bragulla H., Pellmann R. and Reese S. (1996): Das Hufbein mit Periost und Insertionszone des Hufbeinträgers. Wiener Tierärztl. Mschr. 84, 241-247

Burn J. F. and Brockington C. (2001): Quantification of hoof deformation using optical motion capture. Equine Vet. J. Suppl. 33, 50-53

Butler K. D. (1993): The principles of horseshoeing. II. 3rd printing, Butler Publishing, La Porte, CO 80535, p.117-123

Colles C. M. (1989): The relationship of frog pressure to heel expansion. Equine Vet. J. 21, 13-16

Douglas J. E., Mittal C., Thomason J. J. and Jofriet J. C. (1996): The modulus of elasticity of equine hoof wall: implications for the mechanical function of the hoof. J. Experiment. Biol. 199, 1829-1836

Dyhre-Poulsen P., Smeedegaard H. H., Roed J. and Korsgaard E. (1994): Equine hoof function investigated by pressure transducers inside the hoof and accelerometers mounted on the first phalanx. Equine Vet. J. 26, 362-366 
Fischerleitner F. (1974): Röntgenographische Untersuchungen über den Einfluß der Lageveränderung des Huf-, Strahl- und Kronbeines auf die Mechanik der Hornkapsel des Pferdes im Belastungsgerät. DVM Thesis, University of Veterinary Medicine Vienna, Austria

Habacher F. (1923). Der Huf- und Klauenbeschlag. 5th ed. Wien und Leipzig, W. Braumüller Universitäts-Verlagsbuchhandlung, $p$ 64-71

Hansen N., Buchner H. H. F., Haller J. and Windischbaver G. (2005): Evaluation using hoof wall strain gauges of a therapeutic shoe and a hoof cast with a heel wedge as potential supportive therapy for horses with laminitis. Vet. Surg. 43, 630-636

Hinterhofer C., Stanek C. and Haider H. (2001): Finite Element analysis (FEA) as a model to predict effects of farriery on the equine hoof. Equine Vet. J. Suppl. 33, 58-62

Hinterhofer C., Weißbacher N., Peham C. and Stanek C. (2002): Dreidimensionale Bewegungsanalyse beschlagener Huf - unbeschlagener Huf. In proc.: 17. Arbeitstagung der Fachgruppe Pferdekrankheiten der DVG. 25./26. April, Hannover, Germany, p 12-17

Jordan P., Willneff J., Apuzzo N. D., Weishaupt M., Wistner T. and Aver J. (2001): Photogrammetric measurement of deformations of horses ' hoof horn capsules. In proceedings: SPIE, 4309, 204-21 1

Kainer R. A. (1989): Clinical anatomy of the equine foot. In: Yovich, J. V.: The equine foot. Veterinary Clinics of North America, Equine Practice 5, 1-27

Koenig H. E., Macher R., Polsterer-Heindl E., Sora C. M., Hinterhofer C., Helmreich M. and Boeck P. (2003a): Shock absorbing structures of the equine toe (in German). Wiener Tierärztl. Mschr. 90, 267-273

Koenig H. E., Popescu A., Polsterer-Heindl E. and Hinterhofer C. (2003b): The arcus terminalis in the digit (in German). Pferdeheilkunde 19: 459-462

Lechner J. (1904): Der Huf und seine Mechanik. K \& K Hof- und Staatsdruckerei, p 23-24

Parks A. (2003): The foot and shoeing. In: Diagnosis and management of lameness in the horse. Eds.: Ross, M. W. and Dyson, S. J.; Saunders, St. Louis, Missouri 63146, p 251

Roepstorff L., Johnston C. and Drevemo S. (1999): The effect of shoeing on kinetics and kinematics during stance phase. Equine Vet. J. Suppl. 30, 279-283

Roepstorff L., Johnston C. and Drevemo S. (2001): In vivo and in vitro heel expansion in relation to shoeing and frog pressure. Equine Vet. J. Suppl. 33, 54-57

Thomason J. J. (1998): Variation in surface strain on the equine hoof wall at the midstep with shoeing, gait, substrate, direction of travel and hoof shape. Equine Vet. J. Suppl. 26, 86-95

Weißbacher N. (2001): Untersuchungen zum Hufmechanismus Vergleich des unbeschlagenen Hufes mit verschiedenen Beschlagssituationen mit Hilfe von Dehnungsmessstreifen und einem kinematischen Messsystem. DVM Thesis, University of Veterinary Medicine Vienna, Austria

Willemen M. A., Savelberg H. H. and Barneveld A. (1997): The improvement of the gait quality of sound trotting warmblood horses by normal shoeing and its effects on the load on the lower forelimb. Livestock Prod. Sci. 52, 145-149

Wilson M. W., McGuigan M. P. and Pardou C. (2001): The biomechanical effect of wedged, eggbar and extension shoes in sound and lame horses. AAEP proceedings 47, 339-343

Woergetter C., Hinterhofer C., Gabler C., Koenig H. E. and Stanek C. (2006) Deformation of the equine hoof wall under defined load: a cadaver-limb study using digital photography (submitted at Equine Comparative Exercise Physiology)

Dr. Christine Hinterhofer

Clinic for Orthopaedics in Ungulates

Department $V$

University of Veterinary Medicine Vienna

Veterinärplatz 1

1210 Vienna

Austria

christine.hinterhofer@vet-hiho.at
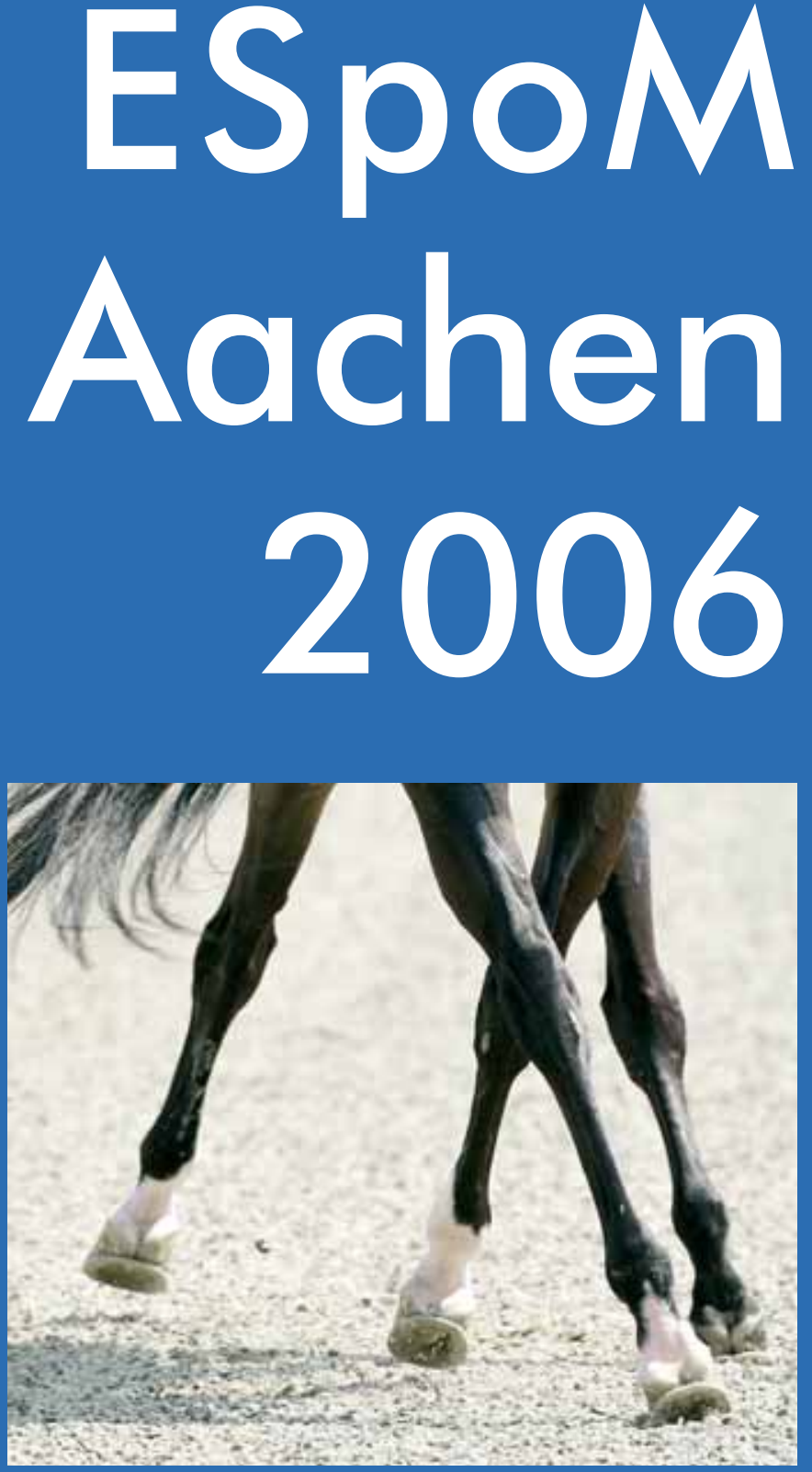

Fortschritte in der Pferde-Sportmedizin Internationaler Tierärztekongress Hufschmiedetagung

während der FEI Weltreiterspiele 23.-26. 8. 2006, Aachen, Eurogress

Seminare Vorträge Posterausstellung Fachmesse Dressurfinale 